\title{
Recent Advances in Substrate-Controlled Asymmetric Cyclization for Natural Product Synthesis
}

\author{
Jeyun Jo ${ }^{1,+}$, Seok-Ho Kim ${ }^{2, \dagger}$, Young Taek Han ${ }^{3}$, Jae-Hwan Kwak ${ }^{4}$ and Hwayoung Yun ${ }^{1, *}$ \\ College of Pharmacy, Pusan National University, Busan 46241, Korea; jju02160@gmail.com \\ 2 College of Pharmacy, Institute of Pharmaceutical Sciences, Cha University, Pocheon-si 11160, Korea; \\ ksh3410@cha.ac.kr \\ 3 College of Pharmacy, Dankook University, Cheonan 31116, Korea; hanyt@dankook.ac.kr \\ 4 College of Pharmacy, Kyungsung University, Busan 48434, Korea; jhkwak@ks.ac.kr \\ * Correspondence: hyun@pusan.ac.kr; Tel.: +82-51-510-2810; Fax: +82-51-513-6754 \\ + These authors contributed equally to this work.
}

Received: 28 May 2017; Accepted: 21 June 2017; Published: 27 June 2017

\begin{abstract}
Asymmetric synthesis of naturally occurring diverse ring systems is an ongoing and challenging research topic. A large variety of remarkable reactions utilizing chiral substrates, auxiliaries, reagents, and catalysts have been intensively investigated. This review specifically describes recent advances in successful asymmetric cyclization reactions to generate cyclic architectures of various natural products in a substrate-controlled manner.
\end{abstract}

Keywords: asymmetric cyclization; substrate-controlled manner; total synthesis; natural product

\section{Introduction}

Asymmetric construction of structurally diverse ring architectures has always been considered a formidable task in natural product synthesis. Various natural sources have provided an enormous number of enantiomerically enriched carbo- and heterocycles [1-5]. Their ring systems include monocycles, such as small-sized, medium-sized, and large-sized rings and polycycles, such as spiro-, fused-, bridged-, and ansa-rings. These intriguing structures have attracted considerable attention from the organic synthesis communities. Many synthetic chemists have explored fascinating tactics to construct chiral ring frameworks using chiral substrates, auxiliaries, reagents, and catalysts [6-8]. In particular the substrate-controlled cyclization strategy, which utilizes the nature of the built-in chiral environment in the starting material, is a very powerful method. In addition, this strategy is more environmentally and economically attractive than using chiral auxiliaries or catalysts $[9,10]$.

The aim of this review is to highlight outstanding achievements in the construction of enantioenriched rings in the field of total synthesis from 2010 to April 2017. Selected original articles in this review contain various substrate-controlled cyclization strategies. The cyclization reactions are categorized by reaction type, such as anionic, cationic, transition metal-mediated, pericyclic, and radical reactions.

\section{Anionic Cyclizations}

Recently, a wide range of natural product syntheses via anionic cyclization in a substrate-controlled manner have been reported. Carreira et al. accomplished the total synthesis of (-)-dendrobine (8) [11], which was isolated from the ornamental orchid Dendrobium nobile Lindl [12,13]. To construct the core of $\mathbf{8}$, they utilized a special cascade sequence including enamine conjugate addition and stereoselective protonation as shown in Scheme 1. Highly advanced precursor 2 was readily prepared from ester $\mathbf{1}$ [14] in twelve steps. Treatment of $\mathbf{2}$ with $\mathrm{N}$-methylbenzylamine followed by exposure to $\mathrm{H}_{2}$ and $\mathrm{Pd} / \mathrm{C}$ led to bicycle 7 in $68 \%$ yield. High diastereoselectivity was obtained 
by a substrate-controlled cascade process involving the conjugate addition of enamine 3 , enamine formation by proton loss of 4 and the convex protonation of enamine 5 . This transformation allowed the asymmetric formations of the important $\mathrm{C}-\mathrm{C}$ bond and the desired pendant amine.

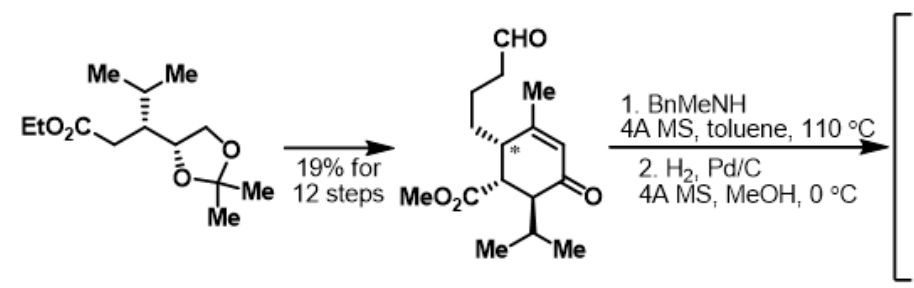

1
2

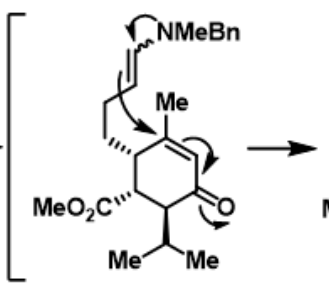

3

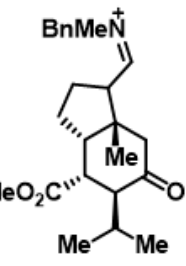

4

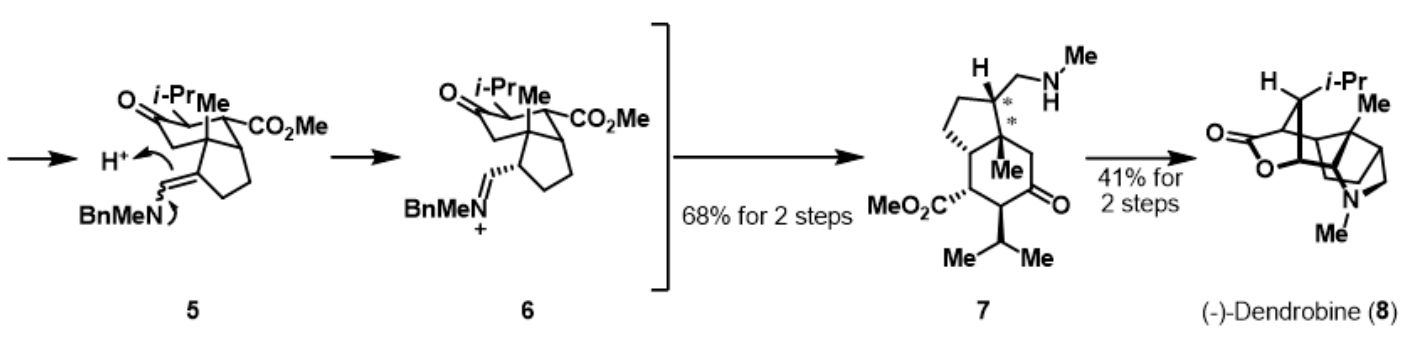

Scheme 1. Total syntheses of (-)-dendrobine (8).

Another substrate-controlled asymmetric cyclization is summarized in Scheme 2 which depicts the total synthesis reported by Tomioka et al. [15] of (-)-kopsinine (17), a Kopsia alkaloid isolated from Kopsia longiflora Merr. in 1955 [16,17]. Key precursor 11 was smoothly formed via a high-yielding process including the asymmetric one-pot $[\mathrm{N}+2+3]$ cyclization of tert-butyl $\mathrm{N}$-Boc-indole-3-propenoate (9) and lithium $N$-benzyltrimethylsilylamide (10). Having successfully inserted two stereocenters onto 11, the three stereocenters of pentacyclic intermediate $\mathbf{1 6}$ were generated in a substrate-controlled manner. Mesylation of $\beta$-ketoester $\mathbf{1 1}$ and subsequent anionic cyclization of the resulting tetracycle $\mathbf{1 4}$ gave optically pure 16, presumably through transition states 12 and $\mathbf{1 5}$. The bridged ring of $\mathbf{1 7}$ was later introduced by Diels-Alder cyclization.<smiles>CCOC(C)=O</smiles>

9

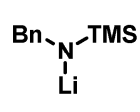

10

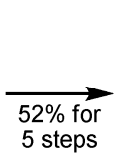

steps<smiles>COC(=O)COC(=O)C1=C(C(=O)OCc2ccccc2)N(CCO)CCC1</smiles>

11 $\frac{\text { 1. } \mathrm{MsCl}, \mathrm{Et}_{3} \mathrm{~N}, \mathrm{CH}_{2} \mathrm{Cl}_{2}}{\text { 2. } \mathrm{KOt}-\mathrm{Bu}, \mathrm{THF} / \mathrm{HMPA},-78{ }^{\circ} \mathrm{C}}$ $61 \%$ for 2 steps

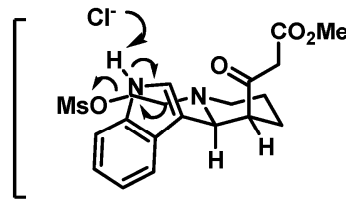

12

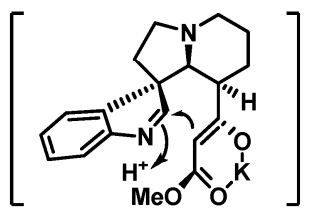

15
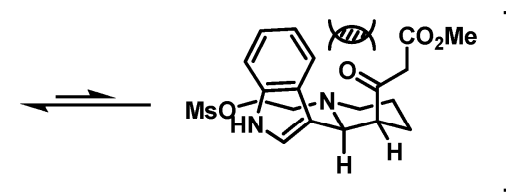

13

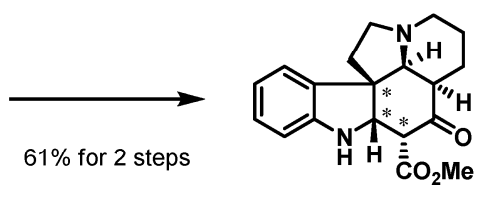

16

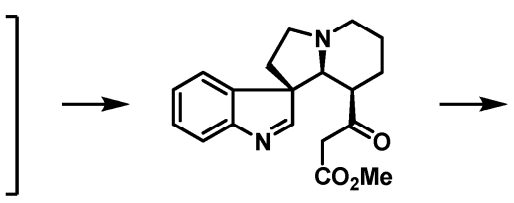

14

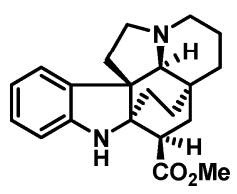

(-)-Kopsinine (17)

Scheme 2. Total synthesis of (-)-kopsinine (17). 
An elegant anionic polycyclization strategy of Deslongchamps et al. led to the total synthesis of $(+)$-cassaine (23) as shown in Scheme 3 [18]. (+)-Cassaine was isolated from Erythrophleum guineense in 1935 and reported as a nonsteroidal $\mathrm{Na}^{+}-\mathrm{K}^{+}$-ATPase inhibitor [19]. (+)-Carvone (18) was selected as the starting building block to synthesize the pharmacologically interesting natural product. The authors successfully prepared cyclization precursor 19 based on their previous synthetic route [20]. With the asymmetric formation of the trans-decalin system of 19, the desired anionic cyclization was performed using Nazarov reagent 20. Thus, treatment with cesium carbonate in EtOAc gave rise to diastereomerically pure tricycle 22 via Michael adduct 21 in $62 \%$ yield. The newly created stereocenters originated from the $\alpha$-face attack of 20 toward 19, which was controlled by the steric repulsion of the angular methyl group in the ring junction of 19. Synthesis of (+)-cassaine (23) was completed through multiple chemical reactions.

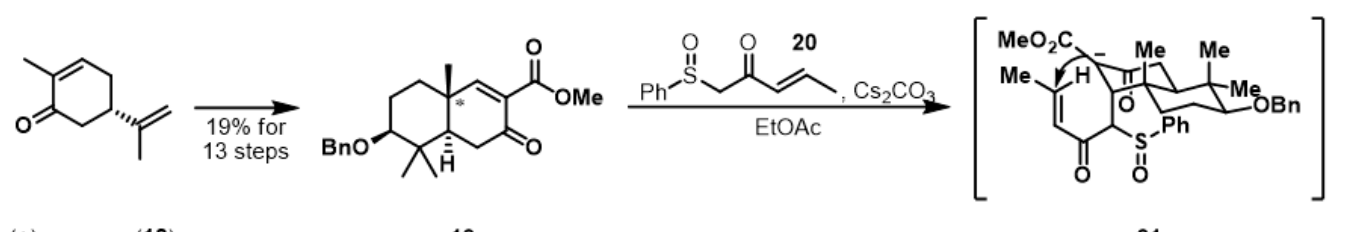

(+)-carvone (18)

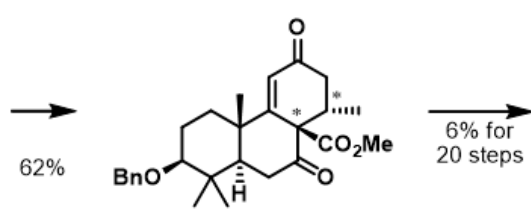

22

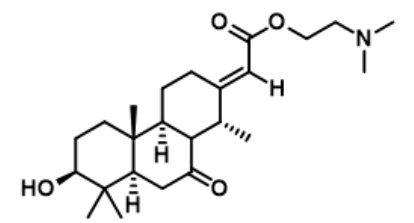

$(+)$-Cassaine $(\mathbf{2 3})$

Scheme 3. Total syntheses of (+)-cassaine (23).

Stereoselective double Michael reactions have also been adopted for the construction of unique ring systems. Shenvi et al. completed the impressive synthesis of (-)-jiadifenolide (31) [21], which is one of the Illicium terpenes [22], as shown in Scheme 4. Key precursors butenolides $\mathbf{2 5}$ and $\mathbf{2 6}$ were quickly synthesized through three- and two-step routes, respectively. The first intermolecular Michael reaction of chiral butenolide $\mathbf{2 5}$ with achiral butenolide $\mathbf{2 6}$ in the presence of lithium diisopropylamide (LDA) provided stable intermediate $\mathbf{2 8}$. The stereochemistry of the process derived from a chelated transition state 27 and the newly created stereocenters of 28 were controlled by the chiral methyl group of 25. Subsequent exposure of the resulting 28 to titanium(IV) isopropoxide and additional LDA finally furnished ketolactone 30 via enolate 29 in 70\% yield. The second intramolecular Michael reaction enabled the construction of the entire skeleton of $\mathbf{3 1}$ in a substrate-controlled manner.

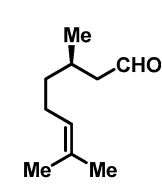

(+)-citronellal (24)

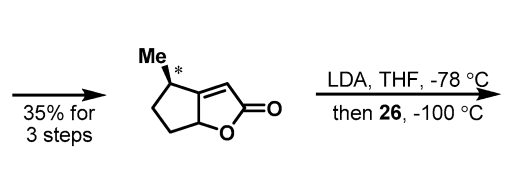

25

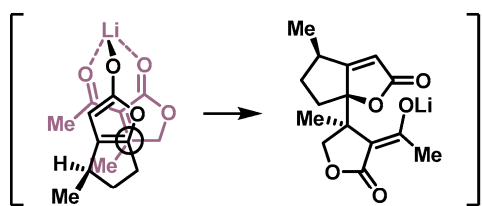

27

28

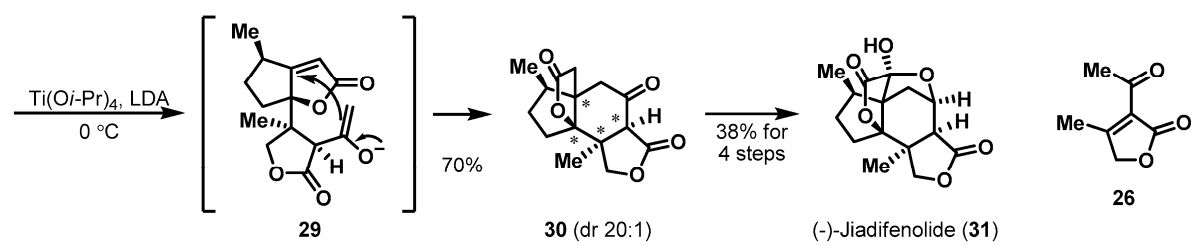

Scheme 4. Total synthesis of (-)-jiadifenolide (31). 


\section{Cationic Cyclizations}

Cation-induced cyclization has been a powerful tool for controlling the stereochemistry of various ring structures in natural product synthesis. The total synthesis of (+)-siebolidine A (37), which is an alkaloid of club moss Lycopodium sieboldii [23], was firstly reported by Overman et al. [24,25]. This landmark synthesis was accomplished with a pinacol-terminated cyclization cascade as depicted in Scheme 5. Cyclization precursor 33 was built from the readily available allylic lactone $32[26,27]$ in 9 steps. Initially, an increased cationic environment of gold alkyne species 34 enabled 1,6-enyne cyclization. The subsequent pinacol shift of cyclized cationic intermediate 35 afforded the desired cis-hydrindanone $\mathbf{3 6}$ as a single stereoisomer. The stereochemistry of enyne $\mathbf{3 3}$ was efficiently reorganized in a substrate-controlled manner.
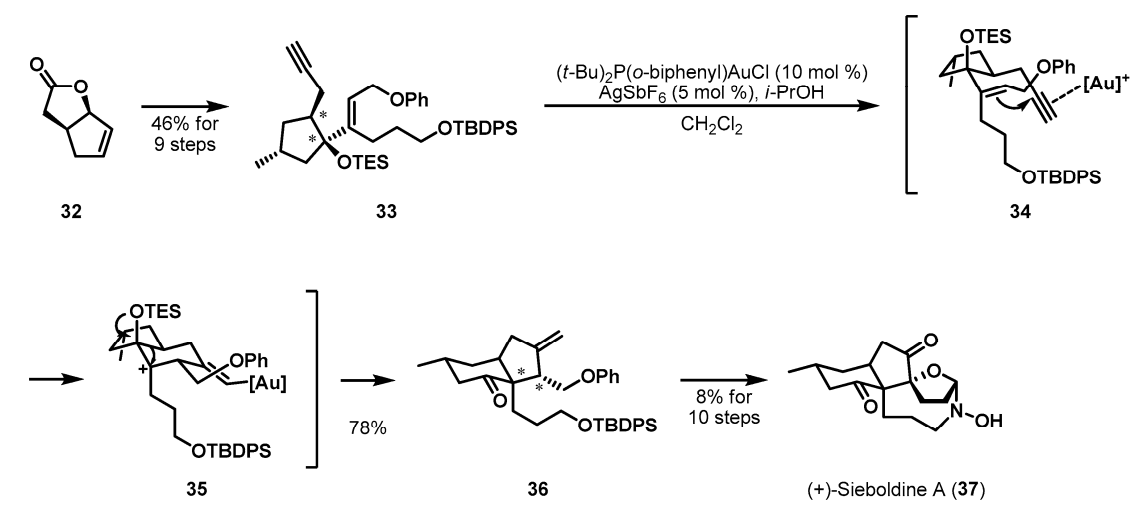

Scheme 5. Total synthesis of (+)-sieboldine A (37).

Another interesting example of substrate-controlled cyclization is the total synthesis of (-)-zampanolide (42) published by Ghosh et al. [28,29] (Scheme 6). (-)-Zampanolide was initially separated from the marine sponge Fasciospongia rimosa and exhibited a potent microtubulestabilizing activity [30,31]. Synthesis of interesting macrolide 42 commenced from the known ester 38, which was effectively prepared by the Noyori hydrogenation procedure [32]. Optically active starting material 38 was converted to allylsilane 39 in three steps. With the desired starting material 39 in hand, the authors carried out an oxidative Sakurai type cyclization using 2,3-dichloro-5,6-dicyano-1,4-benzoquinone (DDQ) with mild Brønsted acid pyridinium $p$-toluenesulfonate (PPTS). Cyclized product 41 was obtained diastereoselectively through the Zimmerman-Traxler transition state 40. The cis-stereochemistry of tetrahydropyran ring $\mathbf{4 1}$ was caused by the equatorial orientations of all substituents in $\mathbf{4 0}$. Having successfully assembled the core ring, macrocycle $\mathbf{4 2}$ was successfully constructed via cross and ring-closing metatheses.
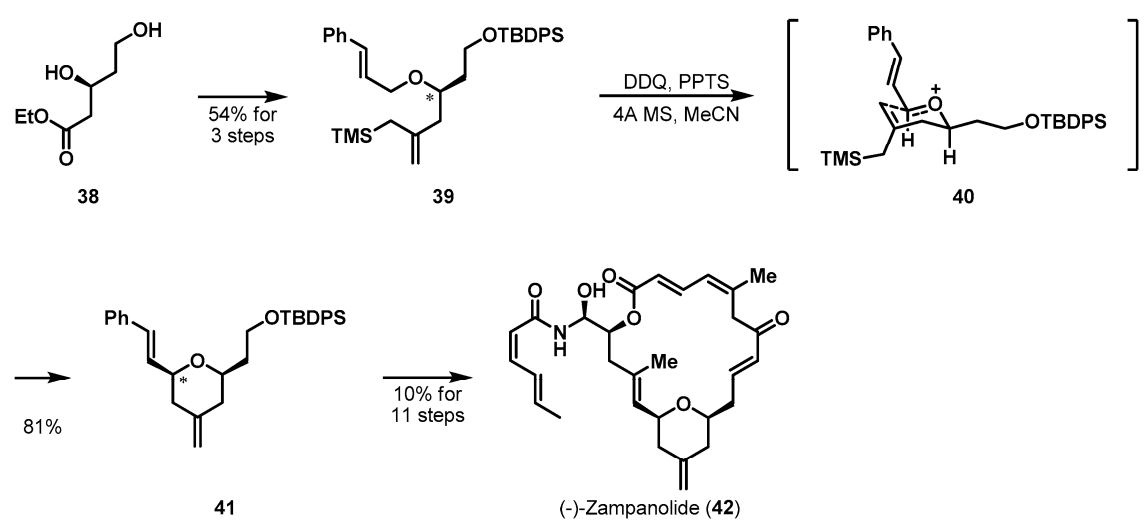

Scheme 6. Total synthesis of (-)-zampanolide (42). 
Natural product clusianone is one of the polyprenylated polycyclic acylphloroglucinols (PPAPs) possessing a structurally unique bicyclo[3.3.1]nonane-2,4,9-trione core [33]. A biomimetic cationic cyclization was applied to construct the bicyclic template of (-)-clusianone (48) as shown in Scheme 7 [34]. Porco Jr. et al. were interested in the synthesis and structure-activity relationship of PPAP natural products and derivatives. Cyclization precursor 44 was accessible from starting material 43 via an unprecedented alkylative dearomatization strategy. Thus, when optically active 44 was subjected to neat formic acid, a tertiary carbocation was initially formed, which led to the intramolecular attack of the methyl enol ether to stereoselectively furnish the desired bicycle 47 in $72 \%$ yield. The authors proposed the transition states $\mathbf{4 5}$ and $\mathbf{4 6}$ due to the observation of formate adduct from ultrahigh performance liquid chromatography (UPLC) measurements. A final olefin metathesis produced (-)-clusianone (48).

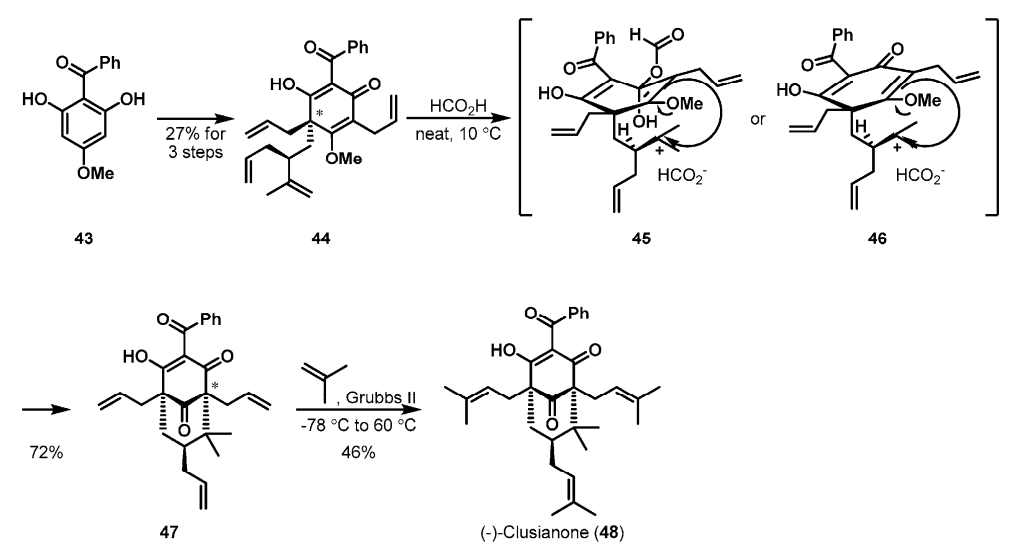

Scheme 7. Total synthesis of (-)-clusianone (48).

As depicted in Scheme 8, another biomimetic cationic cyclization study was performed by Takayama et al. [35]. Lycopodium alkaloids (+)-flabellidine (55) and (-)-lycodine (56) were reported from Lycopodium complanatum in 1942 and Lycopodium annotinum in 1958, respectively [36,37]. The methyl group of linear precursor $\mathbf{5 0}$ was diastereoselectively introduced by Hosomi-Sakurai allylation of commercially available crotonamide 49 [38]. With linear substrate 50 in hand, the authors examined the designed cationic cascade cyclization to form the tetracyclic backbone. Exposure of 50 in $\mathrm{CH}_{2} \mathrm{Cl}_{2}$ to an excess amount of (+)-camphorsulfonic acid (CSA) provided tetracycle $\mathbf{5 4}$ as the major product, presumably through conjugate addition of ene-iminium intermediate $\mathbf{5 1}$ and olefin migration of $\mathbf{5 2}$, Mannich-like reaction of 53 . The diastereoselectivity was dominantly controlled by the stereocenter of the methyl group. After protecting group manipulation a minor diastereomer of the cationic cascade cyclization could be removed, and syntheses of (+)-flabellidine (55) and (-)-lycodine (56) were completed by a chemoselective acetylation and selective IBX oxidation, respectively.
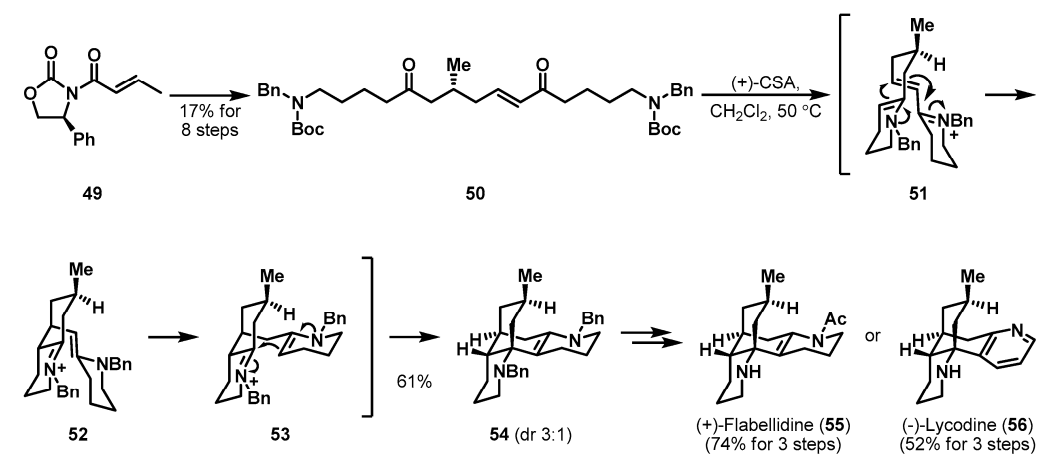

Scheme 8. Total syntheses of (+)-flabellidine (55) and (-)-lycodine (56). 
More recently, a protecting-group-free total synthesis of (-)-lycopodine (63) was described (Scheme 9). (-)-Lycopodine is one of the Lycopodium alkaloids and was originally isolated from Lycopodium complanatum in 1881 [39]. To construct its polycyclic architecture, She et al. employed an acid-promoted aza-Prins cyclization [40]. Cyclization substrate 58 was smoothly synthesized from $(R)$-pulegone (57) via Wade's enone synthesis, a one-pot amidation, and cyclization [41]. Alkyne-enamide 58 was subjected to a phosphoric acid-promoted cyclization and the desired product 62 was obtained in almost quantitative yield. Initially, enamine $\mathbf{5 8}$ was protonated stereoselectively to furnish $\mathrm{N}$-acyliminium 59. Subsequent intramolecular 6-exo-trig cyclization provided unstable carbocation species $\mathbf{6 0}$, which was quickly transformed to enol $\mathbf{6 1}$ via the capture of water. Further manipulation, including an intramolecular aldol cyclization, led to completion of the synthesis of (-)-licopodine (63).

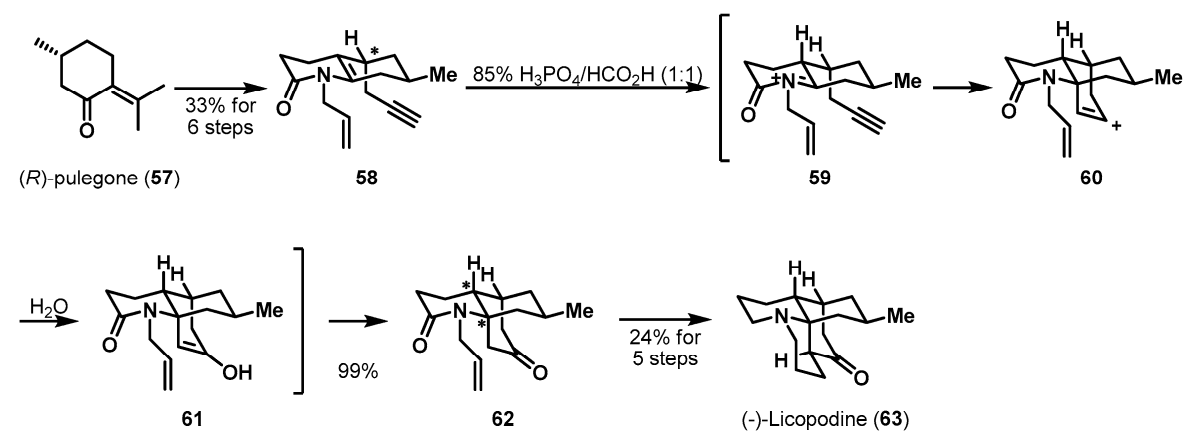

Scheme 9. Total synthesis of (-)-lycopodine (63).

\section{Transition Metal-Mediated Cyclizations}

Transition metals have been used as powerful reagents for cyclization in the synthesis of complex natural products. The enantioselective total synthesis of (+)-isolysergol (69) [42], one of the biologically important ergot alkaloids [43], was completed by Fujii and Ohno et al. The authors examined a special palladium-catalyzed domino cyclization to build the ergot alkaloid backbone (Scheme 10). Allenic amide 65, required for the cyclization, was prepared from commercially available 4-bromoindole (64). Successful substrate-controlled cyclization of allene 65 in the presence of $5 \mathrm{~mol} \%$ of $\mathrm{Pd}\left(\mathrm{PPh}_{3}\right)_{4}$ and $\mathrm{K}_{2} \mathrm{CO}_{3}$ was achieved leading to the desired product 68 in $76 \%$ yield with high diastereoselectivity. After oxidative addition, aminopalladation of the indolylpalladium halide proceeded via the conformation 66 to provide alkenylpalladium(II) intermediate 67 . The stereochemistry of the ring junction in 68 ultimately derived from chiral allene 65.

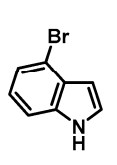

64

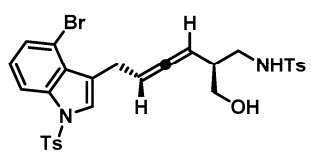

65

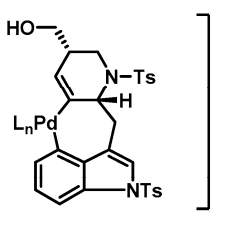

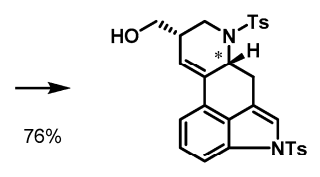

$68(d r=92: 8)$
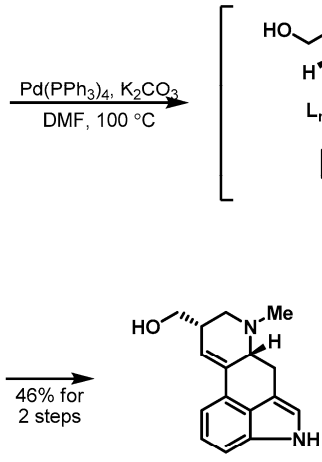

(+)-Isolysergol (69)

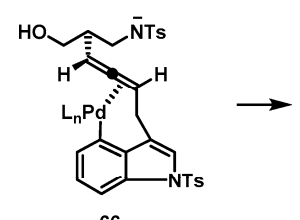

66

Scheme 10. Total synthesis of (+)-isolysergol (69). 
The nickel-mediated carboxylative cyclization of enyne precursor is another example of a transition-metal mediated cyclization as depicted in Scheme 11. Sato et al. described the total synthesis of indole alkaloid (-)-corynantheidine (76) [44], which was first reported in 1944 from the African plant Pseudocinchona africana [45]. Desired enyne $\mathbf{7 1}$ was readily accessible from L-tryptophan (70) in an optically active form through a sequence of usual transformations involving a cis-selective Pictet-Spengler reaction [46]. Upon treatment of precursor $\mathbf{7 1}$ with a stoichiometric amount of $\mathrm{Ni}(\mathrm{cod})_{2}$ and 1,8-diazabicyclo[5.4.0] undec-7-ene (DBU) under an atmosphere of gaseous $\mathrm{CO}_{2}$, the crude materials were obtained. Hydrolysis and methylation of the crude nickelacycle $\mathbf{7 3}$ stereoselectively led to the desired tetracycle 75 in $73 \%$ yield. The fourth ring was formed through oxidative cycloaddition of 71 and subsequent insertion of $\mathrm{CO}_{2}$ between the $\mathrm{C}_{\mathrm{sp} 3}$-nickel bond in 73 . The new stereogenic center of the ring junction in $\mathbf{7 5}$ was created by an asymmetric formation of the nickelacycle in a substrate-controlled manner.

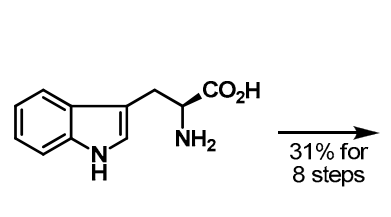

70

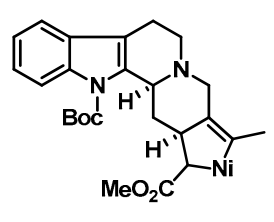

73

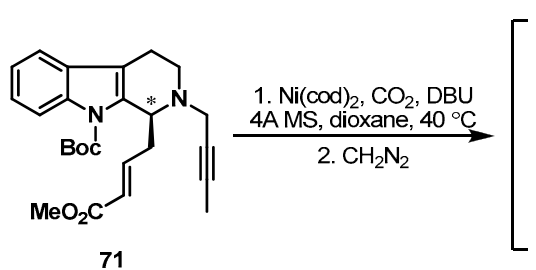

71

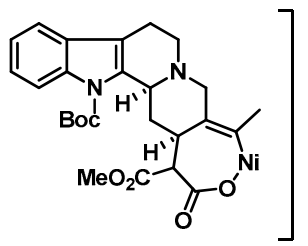

74

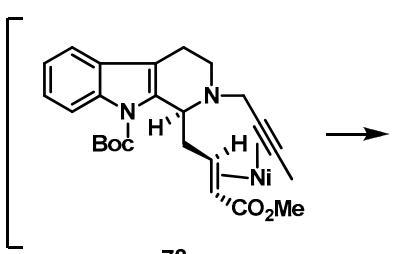

72

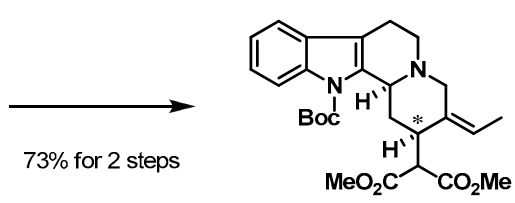

75 (single isomer)

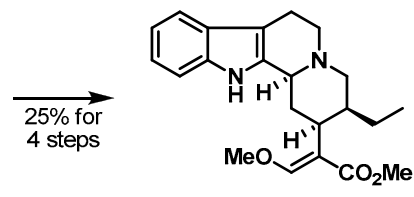

(-)-Corynantheidine (76)

Scheme 11. Total synthesis of (-)-corynantheidine (76).

The asymmetric synthesis of incarvillea alkaloids was studied by using palladium(0)-catalyzed cyclization. Suh et al. completed an enantioselective synthesis of 7-epi-incarvilline (77) [47], which is an advanced architecture for the formal syntheses of (-)-incarvilline (78), (+)-incarvine $C(79)$, and (-)-incarvillateine (80) (Scheme 12). Structurally, they consist of a common bicyclic piperidine skeleton including five contiguous stereocenters [48-50]. The authors focused on the diastereoselective construction of key intermediate 85, a highly functionalized bicyclic lactone containing three stereocenters. The desired precursor 82 of the reaction was easily obtained from the known chiral tosylate $\mathbf{8 1}$ [51]. Exposure of $\mathbf{8 2}$ in THF to $\mathrm{Pd}(\mathrm{dppb})_{2}$ resulted in the desired bicyclic lactone 85 in $90 \%$ yield and with excellent diastereoselectivity ( $>29: 1)$. The two transition states, 83 and $\mathbf{8 4}$, were controlled by the built-in chirality of lactone 82 and the high diastereoselectivity likely occurred due to the steric repulsion between the benzenesulfonyl group and the $\mathrm{R}$ substituent in $\mathrm{Pd}-\pi$-allyl complex of 83. With the bicyclic lactone 85 in hand, 7-epi-incarvilline (77) was synthesized using further manipulations such as a substrate-controlled catalytic hydrogenation and a 1,4-addition. 


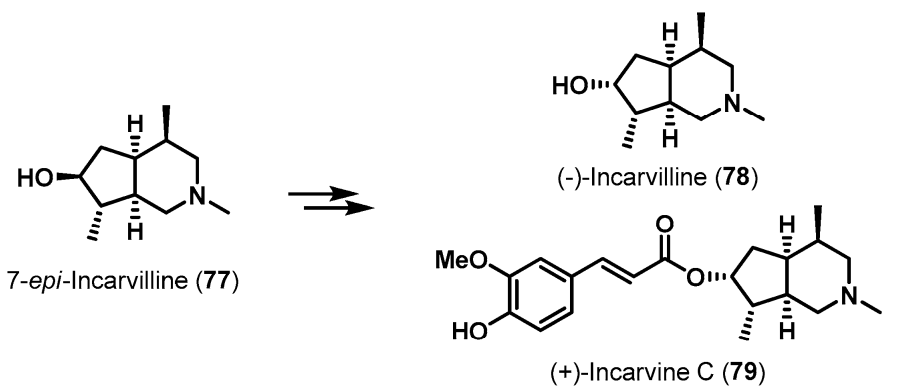

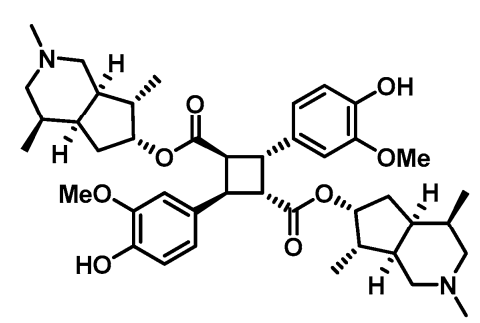

(-)-Incarvillateine (80)

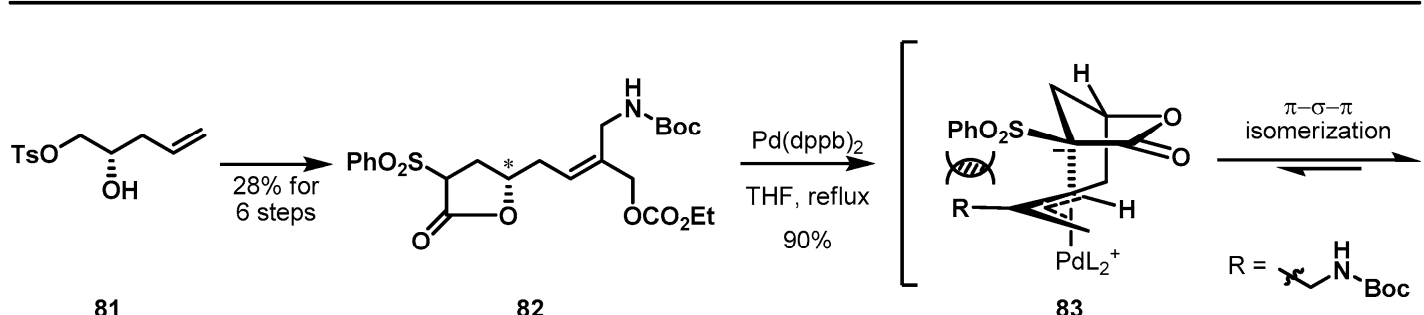

81

82

83

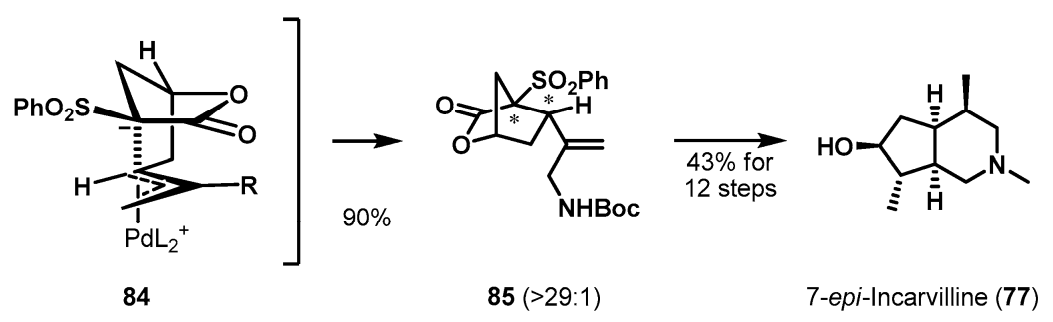

Scheme 12. Synthesis of 7-epi-incarvilline (77).

Metal-catalyzed carbenoid transfer is also a useful method for asymmetric cyclizations. Bolivianine was isolated from Hedyosmum angustifolium (Chloranthaceae) in 2007 [52]. The sesterterpenoid natural product consists of a highly complex heptacyclic skeleton and nine stereocenters. Liu et al. reported a bioinspired total synthesis of bolivianine (90), which is summarized in Scheme 13. [53,54]. Precursor tosylhydrazone 87 was well designed for the formation of the chiral cyclopropyl moiety in $\mathbf{8 9}$ and produced from commercially available (+)-verbenone (86). The programmed intramolecular cyclopropanation of $\mathbf{8 7}$ with a palladium catalyst and a sodium salt afforded the desired product 89 as the sole isolable diastereomer in $65 \%$ yield. The stereochemistry of the chiral cyclopropane was substrate-controlled via allylic metal carbene species 88 , which its conformation was caused by an equatorial positioning of two alkyl chains in chair-like transition state.

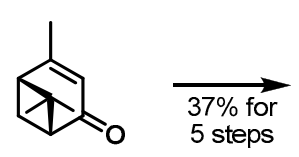

(+)-verbenone (86)

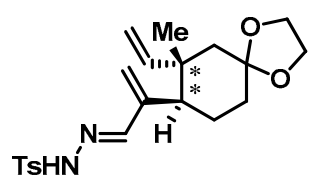

87

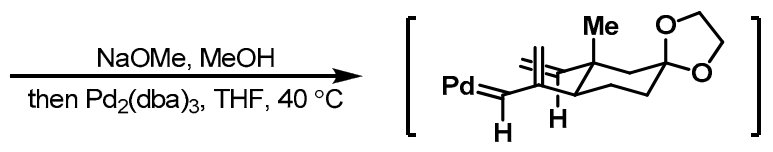

88

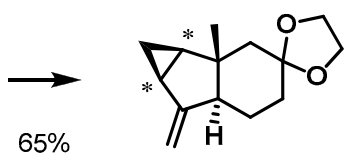

89

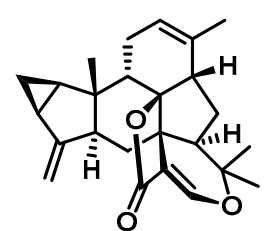

Bolivianine (90)

Scheme 13. Total synthesis of bolivianine (90). 


\section{Pericyclic Reactions}

Diverse types of pericyclic reactions have been used as an attractive tactic for substrate-controlled asymmetric cyclizations. Structurally interesting fluvirucins were isolated from actinomycetes by scientists from Bristol-Myers Squibb [55-58] and Schering-Plough [59,60] independently. Suh et al. employed a stereoselective aza-Claisen rearrangement-promoted ring expansion in the total synthesis of antibiotic macrolactam fluvirucinine $A_{1}$ (95), an aglycon of fluvirucine $A_{1}$ (Scheme 14) [61]. The key precursor, 10-membered $\alpha$-alkoxyvinyl acylazacycle $\mathbf{9 2}$, was obtained from piperidine $\mathbf{9 1}$ by a diastereoselective $\alpha$-alkylation of an iminium ion generated from an $\mathrm{N}, \mathrm{O}$-acetal TMS ether [62] . With the functionalized precursor 92 in hand, the projected aza-Claisen reorganization was executed in the presence of lithium bis(trimethylsilyl)amide (LHMDS) in refluxing toluene, to affording 14-membered macrolactam 94. The origin of the stereoselectivity could be explained based on a selective (Z)-lactam enolate formation and an equatorial positioning of the alkoxyvinyl substituent in chair-like transition state 93.

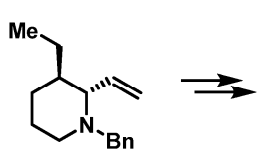

91

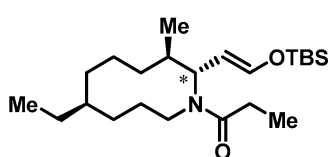

92

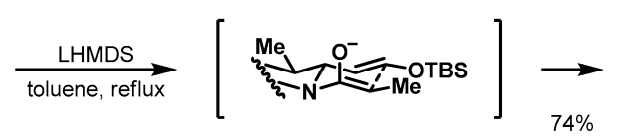

93

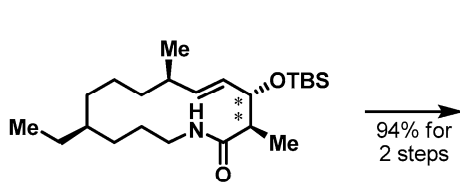

94

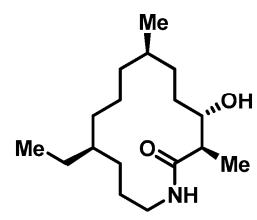

Fluvirucinine $\mathrm{A}_{1}$ (95)

Scheme 14. Total synthesis of fluvirucinine $A_{1}$ (95).

(-)-Lingzhiol and its enantiomer were separated from Ganoderma lucidum in 2013 and found to inhibit selectively p-Smad3 [63]. The architecture of lingzhiol is composed of a carbocyclo[4.3.0]nonane skeleton and two quaternary bridgehead carbons (Scheme 15). Long et al. achieved the total synthesis of (-)-lingzhiol (99) via a rhodium-catalyzed intramolecular [3 + 2] cycloaddition [64]. Important precursor 97 was easily generated from 5,8-dimethoxy-3,4-dihydronaphthalen-1(2H)-one (96) in 10 steps by a ring expansion reaction employing Koser's reagent [65] and an alkynylation using Waser's reagent [66]. Treatment of compound $\mathbf{9 7}$ with the rhodium catalyst in the presence of CO in DCE gave rise to tricycle 98 in a diastereoselective manner. The catalytic cycle underwent a retro-propargylation, Michael reaction, Conia-ene type reaction, and protonolysis. The stereochemistry of the product was transferred stereospecifically from the chirality of the substrate. Further six steps completed the synthesis of (-)-lingzhiol (99).

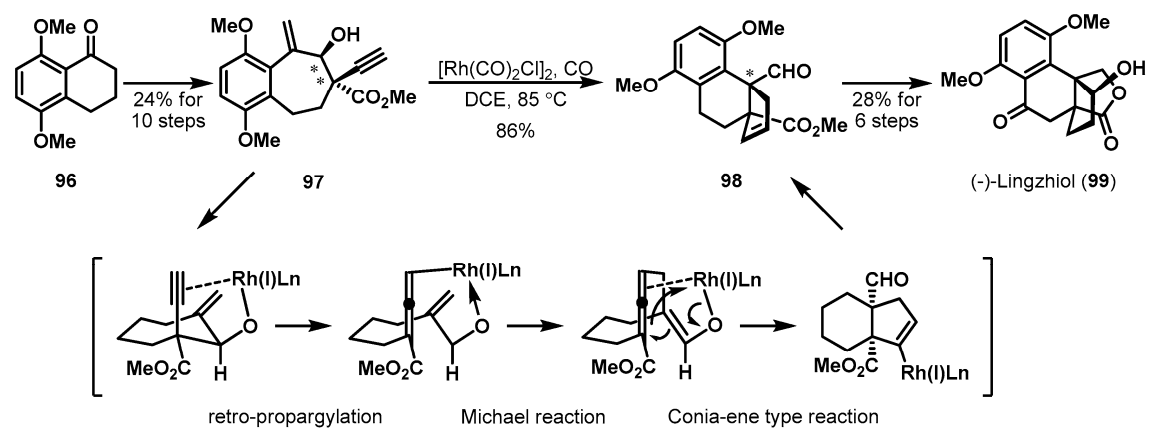

Scheme 15. Total synthesis of (-)-lingzhiol (99). 
Vanderwal et al. recently described the total synthesis of alsmaphorazine B (108) by an intramolecular nitrone/alkene dipolar cycloaddition (Scheme 16) [67]. Alsmaphorazine B possesses a highly dense, oxidized, and cage-like hexacyclic structure with a rare endo $\mathrm{N}-\mathrm{O}$ bond [68]. The authors analyzed the structure of $\mathbf{1 0 8}$ and then proposed an alternative biogenetic hypothesis of multiple oxidations from akuammicine (109). Akuammicine-derived pivotal substrate 101 was prepared from tryptamine (100) by applying a scalable process involving a Diels-Alder reaction and a Heck reaction. Firstly, deoxygenation of $\alpha$-ketol 101 with samarium iodide furnished two diastereomers, 102 and 103, in 1:1.5 ratio. Subsequent DMDO oxidation of the mixture of tertiary amines $\mathbf{1 0 2}$ and $\mathbf{1 0 3}$ readily led to the corresponding $\mathrm{N}$-oxides, 104 and $\mathbf{1 0 5}$. Then, treatment of the obtained $\mathrm{N}$-oxide mixture, 104 and 105, with DBU liberated a hydroxylamine and an enone. Finally, the desired cycloadduct 107 was spontaneously produced in $49 \%$ yield for 3 steps. This surprising sequence proceeded stereoselectively in a substrate-controlled manner.
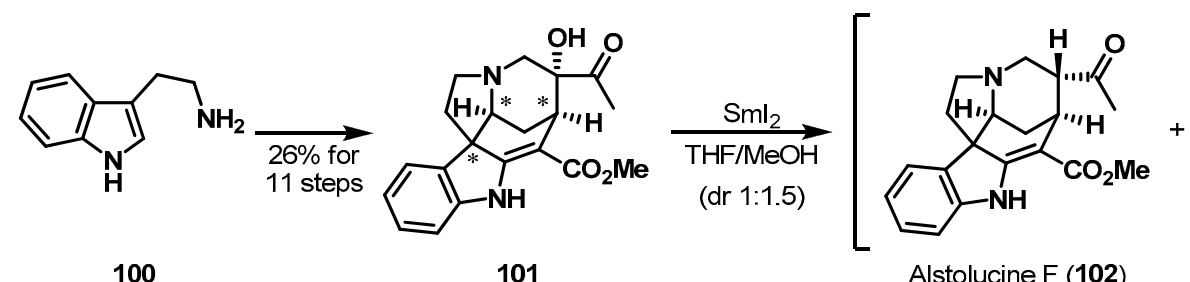

Alstolucine F (102)

DMDO DMDO
acetone,$-78{ }^{\circ} \mathrm{C} \downarrow$
$\downarrow$

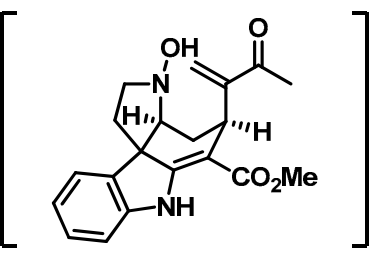

106 $49 \%$ for 3 steps
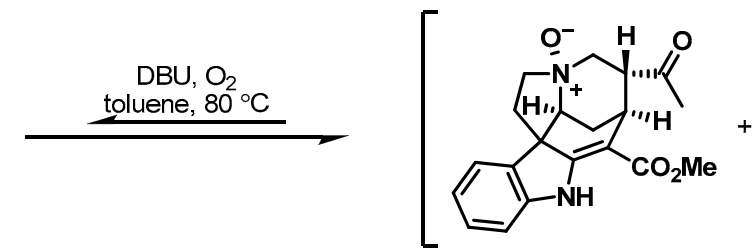

104

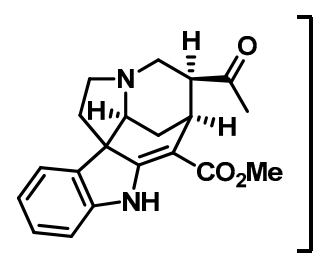

Alstolucine B (103)

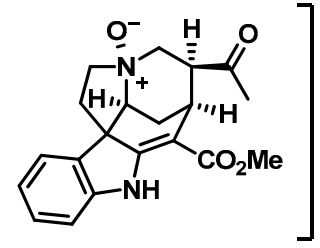

Alstolucine C (105)

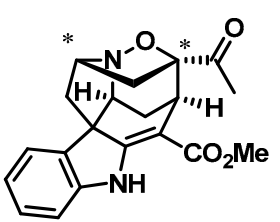

107

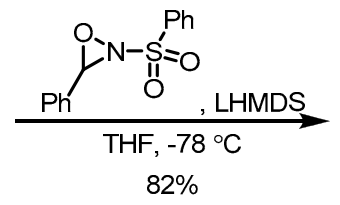

$82 \%$

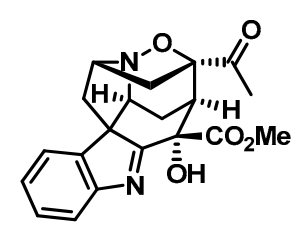

Alsmaphorazine B (108)

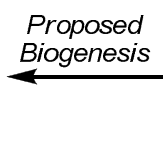

Scheme 16. Total synthesis of alsmaphorazine B (108).

Intramolecular nitrile oxide-olefin cycloaddition (INOC) was utilized to form the macrocyclic moiety of (-)-11ß-hydroxycurvularin (115) (Scheme 17). This polyketide was isolated from Alternaria tomato and contains a 3,5-dihydroxyphenylacetic acid skeleton [69]. Lee et al. described a remote stereoinductive fashion of the key cyclization to synthesize the natural product [70]. Oxime 112, the substrate of nitrile oxide 113, was efficiently prepared from commercially available $\mathbf{1 1 0}$ by esterification, formylation, and oxime formation. Then oxime $\mathbf{1 1 2}$ was subjected to an intramolecular nitrile oxide cycloaddition reaction. It is well known that isolated alkene group has decreased reactivity compared to enone group and that regio- and stereoselectivity can be problematic in large ring formation with remote stereocenter [71]. Unexpectedly, the desired isomer $\mathbf{1 1 4}$ was produced in 79\% yield with good diastereoselectivity. This reaction was an example of unprecedented remote stereoinduction and concomitant macrocyclization. 
<smiles>O=C(O)Cc1cc(OCc2ccccc2)cc(OCc2ccccc2)c1</smiles>

110<smiles>C=CCCC[C@H](C)O</smiles>

111<smiles>[CH]ON(O)COc1cc(OCc2ccccc2)cc(CC(=O)OC(C)CCCC=C)c1C=NO</smiles>

112

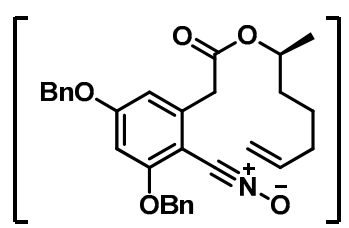

113<smiles>CCCCC(C)OC(=O)Cc1cc(OCc2ccccc2)cc(OC)c1C1=NOC(C)C1</smiles>

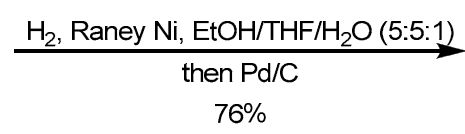

(-)-11ß-Hydroxycurvularin (115)

Scheme 17. Total synthesis of (-)-11ß-hydroxycurvularin (115).

More recently, unified syntheses of denudatine-type diterpenoid alkaloids were disclosed by Sarpong et al. [72]. Among these alkaloids, cochlearenine (120) consists of a highly complex bicyclo[2.2.2] structural architecture and exhibits a bradycardic activity in guinea pig atria [73,74]. Synthesis of cyclization precursor 117 began with the known bicycle 116, which was effectively prepared using Diels-Alder cycloaddition [75] (Scheme 18). Subjecting a solution of dienone 117 in $p$-xylene to heat resulted in the exclusive formation of hexacycle 119, which contains the whole ring backbone of $\mathbf{1 2 0}$. The excellent diastereoselectivity was determined by a substrate-controlled transition state. Total synthesis of cochlearenine (120) was completed in seven steps from hexacycle 119.

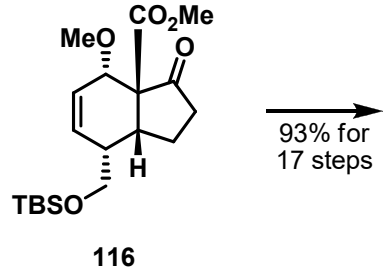

116

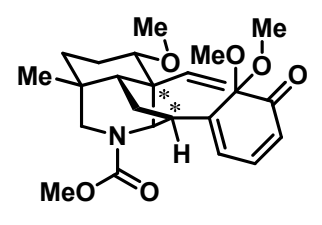

117

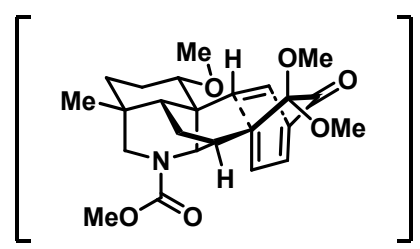

118

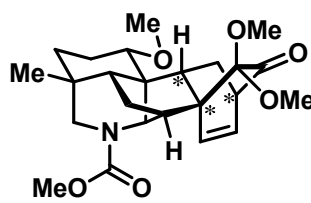

119

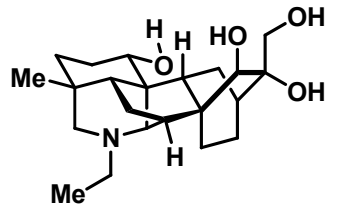

Cochlearenine (120)

Scheme 18. Total synthesis of cochlearenine (120).

\section{Radical Cyclizations}

Radical cyclizations have served as a useful strategy to create various ring systems. As shown in Scheme 19, a total synthesis of the akuammiline alkaloid (+)-scholarisine A (127) was completed by Snyder et al. [76]. The structurally unique alkaloid, which was isolated from Alstonia scholaris, contains an indolenine fused to a strained carbocyclic cage and several tertiary and quaternary stereogenic centers [77]. To access the cage architecture of 126, a tandem 6-exo-trig radical cyclization/Keck allylation was explored. The key precursor 122 of the tandem reaction was efficiently prepared in three steps from acrylate $\mathbf{1 2 1}$ [78]. Substrate $\mathbf{1 2 2}$ was smoothly cyclized using allyltributylstannane and the radical initiator $\mathrm{Et}_{3} \mathrm{~B}$ [79] in benzene at $75{ }^{\circ} \mathrm{C}$, providing the desired 126 in $59 \%$ yield as a single 
diastereomer. The transformation likely progressed in the mechanistic fashion shown in Scheme 19 through the initial radical formation of 123, 6-exo-trig cyclization onto the Michael accepter of 124, and allylation of the resulting 125. The newly incorporated stereogenic centers were influenced by the asymmetric geometry of bicyclic lactone $\mathbf{1 2 2}$.<smiles>C=CC(=O)C1COC(C)(C)N1C(=O)OCCCCC(C)(C)C</smiles>

121

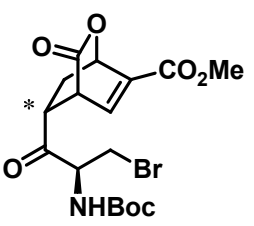

122

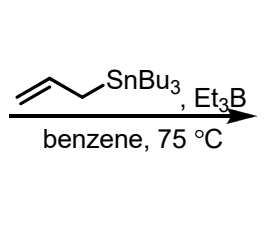<smiles>COC(=O)C1CC2OC(=O)C1O2</smiles>

123

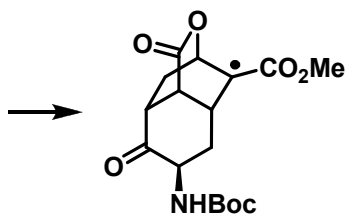

124

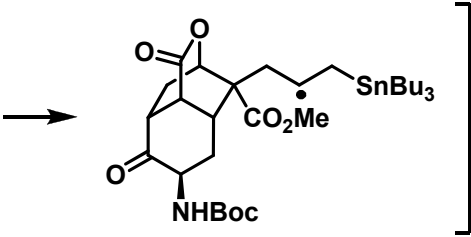

125

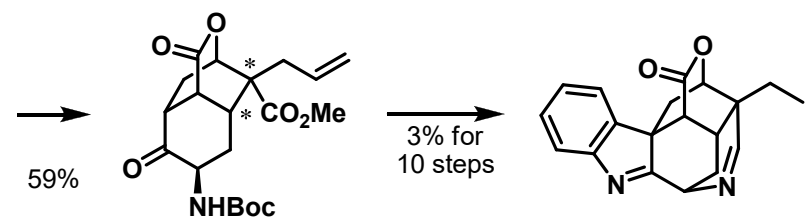

126

(+)-Scholarisine A (127)

Scheme 19. Total synthesis of (+)-scholarisine (127).

Another remarkable radical cyclization was reported by Zakarian et al. (Scheme 20) [80]. Maoecrystal V (133), a cytotoxic diterpenoid, was discovered in 2004 from Isodon eriocalyx, a Chinese medicinal herb [81]. Structurally, three contiguous quaternary stereocenters are compactly arranged on a pentacyclic framework; the complex molecular architecture provides an intriguing synthetic challenge. Key precursor 129, having two quaternary stereocenters, was synthesized from alcohol 128 through a C-H-insertion and a [4+2] cycloaddition. With phenylselenocarbonate 129 in hand, a substrate-controlled radical cyclization was explored. To a solution of substrate $\mathbf{1 2 9}$ in benzene at $80{ }^{\circ} \mathrm{C}$ was slowly added a mixture of $\mathrm{TMS}_{3} \mathrm{SiH}$, as a less efficient hydrogen atom donor reagent, and AIBN, resulting in the formation of lactone 132 (55\% yield). The asymmetric cyclization successfully generated the third quaternary stereocenter of $\mathbf{1 3 2}$ through the initially generated formyl radical 130.

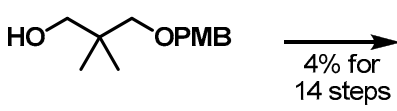

128

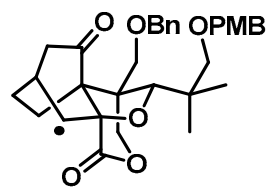

131

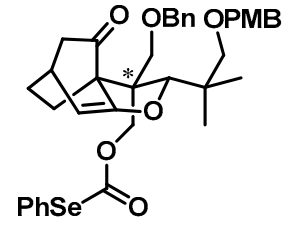

129

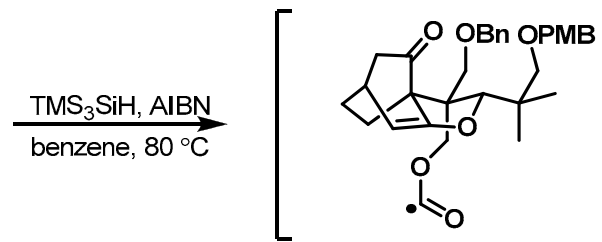

130

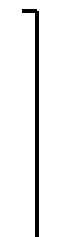

$\stackrel{[\mathrm{He}]}{\longrightarrow}$

$55 \%$

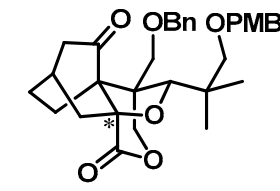

132

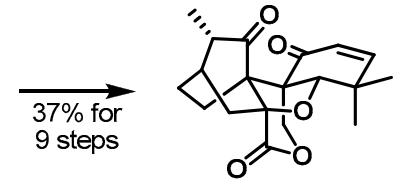

Maoecrystal $\vee(133)$

Scheme 20. Total synthesis of maoecrystal V (133). 
Ma et al. described the total syntheses of leucosceptroids A (139) and B (138) by applying a $\mathrm{SmI}_{2}$-mediated intramolecular ketyl-olefin radical cyclization (Scheme 21) [82]. These two sesterterpenoids were separated from glandilar trichomes of Leucosceptrum canum [83]. These intriguing compounds contain a common tricyclic hydrindane ring skeleton and eight contiguous stereogenic centers. Advanced intermediate $\mathbf{1 3 5}$ was smoothly accessed from commercially available enynol $\mathbf{1 3 4}$. Exposure of $\mathbf{1 3 5}$ to samarium(II) iodide gave rise to fused tricycle 137 through ketyl radical species 136 in a substrate-controlled manner. The $\alpha$-OTMS unit of $\mathbf{1 3 6}$ played a critical role to promote selective 6-exo-cyclization, which competed with 7-endo-cyclization, by blocking the chelation of the free hydroxy group to $\mathrm{SmI}_{2}$, and high diastereoselectivity by decreasing the steric repulsion with the olefin. Further transformations efficiently led to completion of the syntheses of leucosceptroids A (139) and B (138).

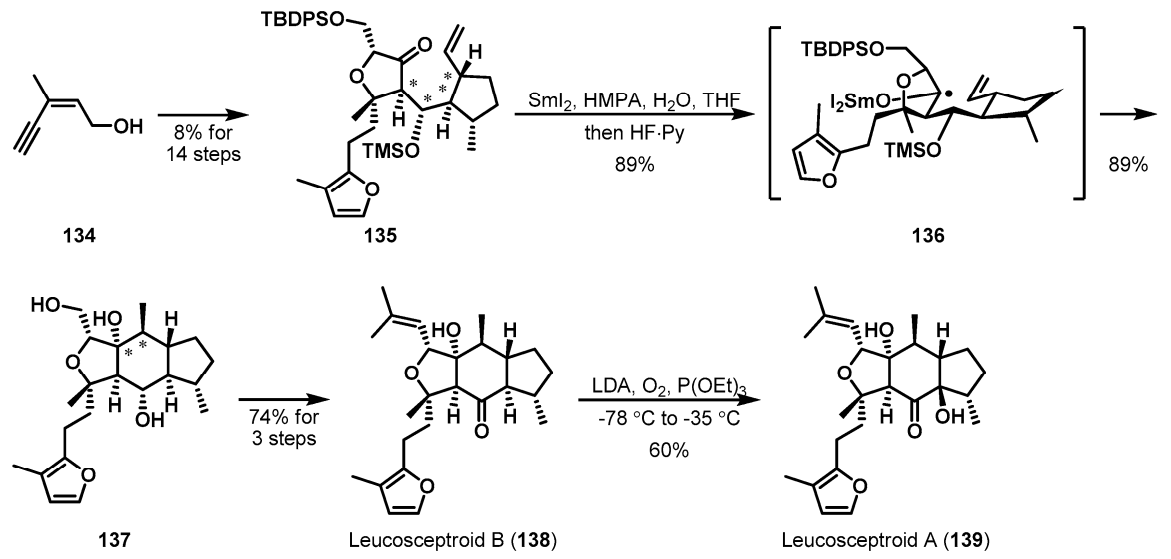

Scheme 21. Total syntheses of leucosceptroids A (139) and B (138).

More recently, a remarkable photochemical C-H acylation was utilized to cyclize a complicated ring system (Scheme 22). Inoue et al. presented a total synthesis of zaragozic acid C (145) [84], a potent inhibitor of mammalian squalene synthase [85]. Natural acid $\mathbf{1 4 5}$ is characterized by a dioxabicyclo[3.2.1] octane architecture with an array of six stereocenters. Pivotal radical cyclization precursor 141 was produced from commercially available gluconolactone derivative 140. Irradiation of highly oxygenated substrate $\mathbf{1 4 1}$ with violet LED light excited the 1,2-diketone moiety and the resulting 1,2-biradical 142 spontaneously generated 1,4-biradical 143 via a hydrogen atom abstraction of the proximal ethereal $\mathrm{C}-\mathrm{H}$ bond. The facile $\mathrm{C}-\mathrm{C}$ bond formation of the 1,4-biradical 143 stereoselectively afforded the desired bicycle 144 ( $54 \%$ yield) by avoiding steric repulsions between the bulky substituents. Careful functional group transformations provide final product 145.
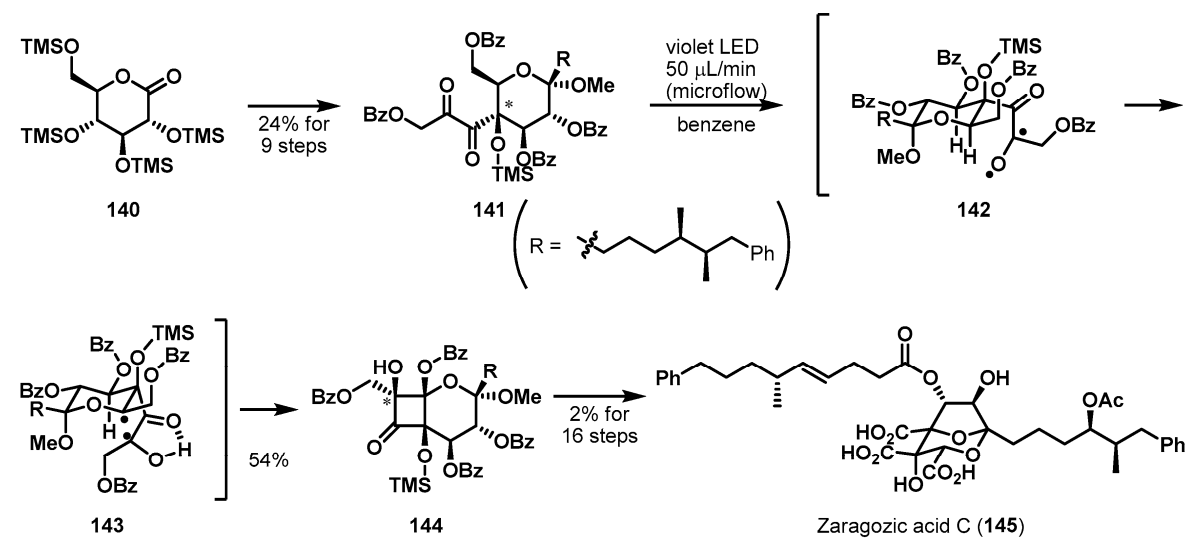

Scheme 22. Total synthesis of zaragozic acid C (145). 


\section{Conclusions}

Substrate-controlled asymmetric cyclizations provide organic chemists with a powerful tool for the construction of optically active ring frameworks of natural products. In this review, a remarkable variety of cyclizations were classified by reaction type, such as anionic, cationic, transition metal-mediated, pericyclic, and radical reaction and discussed in detail. Various ring systems of natural products and their newly generated stereocenters were successfully established and defined. To conclude, asymmetric cyclization induced by the chiral nature of the substrate is in continuous development for the synthesis of natural products and related compounds.

Acknowledgments: This research was supported by Basic Science Research Program through the National Research Foundation of Korea (NRF) funded by the Ministry of Science, ICT \& Future Planning (2015R1C1A1A02036681) and the Bio \& Medical Technology Development Program of the National Research Foundation (NRF) funded by the Ministry of Science, ICT \& Future Planning, Republic of Korea (NRF-2016M3A9A5916225).

Author Contributions: All authors contributed to and approved the final manuscript.

Conflicts of Interest: The authors declare no conflict of interest.

\section{Abbreviations}

The following abbreviations are used in this manuscript:

$\begin{array}{ll}\text { Ac } & \text { Acetyl } \\ \text { AIBN } & \text { Azobisisobutyronitrile } \\ \text { Bn } & \text { Benzyl } \\ \text { Boc } & \text { t-Butoxycarbonyl } \\ \text { Bu } & \text { Butyl } \\ \text { Bz } & \text { Benzoyl } \\ \text { cod } & \text { 1,5-Cyclooctadiene } \\ \text { CSA } & \text { Camphorsulfonic acid } \\ \text { dba } & \text { Dibenzylideneacetone } \\ \text { DBU } & \text { 1,8-Diazabicyclo[5.4.0]undec-7-ene } \\ \text { DCE } & \text { 1,2-Dichloroethane } \\ \text { DDQ } & \text { 2,3-Dichloro-5,6-dicyano-1,4-benzoquinone } \\ \text { DMDO } & \text { Dimethyldioxirane } \\ \text { DMF } & \text { N,N-Dimethylformamide } \\ \text { dppb } & \text { 1,4-Bis(diphenylphosphino)butane } \\ \text { Et } & \text { Ethyl } \\ \text { HMPA } & \text { Hexamethylphosphoramide } \\ \text { IBX } & o \text {-Iodoxybenzoic acid } \\ \text { LDA } & \text { Lithium diisopropylamide } \\ \text { LED } & \text { Light emitting diode } \\ \text { LHMDS } & \text { Lithium bis(trimethylsilyl)amide } \\ \text { Me } & \text { Methyl } \\ \text { MS } & \text { Molecular sieves } \\ \text { Ms } & \text { Mesyl } \\ \text { Ph } & \text { Phenyl } \\ \text { PMB } & 4 \text {-Methoxybenzyl } \\ \text { PPTS } & \text { Pyridinium } p \text {-toluenesulfonate } \\ \text { Pr } & \text { Propyl } \\ \text { Py } & \text { Pyridine } \\ \text { TBDPS } & t \text {-Butyldiphenylsilyl } \\ \text { TBS } & t \text {-Butyldimethylsilyl } \\ \text { TES } & \text { Triethylsilyl } \\ \text { THF } & \text { Tetrahydrofuran } \\ \text { TMS } & \text { Trimethylsilyl } \\ \text { Ts } & p \text {-Toluenesulfonyl } \\ & \end{array}$




\section{References}

1. Kobayashi, J.; Kubota, T. The Daphniphyllum alkaloids. Nat. Prod. Rep. 2009, 26, 936-962. [CrossRef] [PubMed]

2. Jin, Z. Muscarine, imidazole, oxazole, and thiazole alkaloids. Nat. Prod. Rep. 2011, 28, 1143-1191. [CrossRef] [PubMed]

3. Kulcitki, V.; Harghel, P.; Ungur, N. Unusual cyclic terpenoids with terminal pendant prenyl moieties: From occurrence to synthesis. Nat. Prod. Rep. 2014, 31, 1686-1720. [CrossRef] [PubMed]

4. Hanson, J.R. Diterpenoids of terrestrial origin. Nat. Prod. Rep. 2015, 32, 1654-1663. [CrossRef] [PubMed]

5. Li, R.; Morris-Natschke, S.L.; Lee, K.H. Clerodane diterpenes: Sources, structures, and biological activities. Nat. Prod. Rep. 2016, 33, 1166-1226. [CrossRef] [PubMed]

6. Moyano, A.; Rios, R. Asymmetric organocatalytic cyclization and cycloaddition reactions. Chem. Rev. 2011, 111, 4703-4832. [CrossRef] [PubMed]

7. Gulder, T.; Baran, P.S. Strained cyclophane natural products: Macrocyclization at its limits. Nat. Prod. Rep. 2012, 29, 899-934. [CrossRef] [PubMed]

8. Nicolaou, K.C.; Hale, C.R.H.; Nilewski, C.; Ioannidou, H.A. Constructing molecular complexity and diversity: Total synthesis of natural products of biological and medicinal importance. Chem. Soc. Rev. 2012, 41, 5185-5238. [CrossRef] [PubMed]

9. Newhouse, T.; Baran, P.S.; Hoffmann, R.W. The economies of synthesis. Chem. Soc. Rev. 2009, 38, 3010-3021. [CrossRef] [PubMed]

10. Paek, S.-M.; Jeong, M.; Jo, J.; Heo, Y.M.; Han, Y.T.; Yun, H. Recent advances in substrate-controlled asymmetric induction derived from chiral pool $\alpha$-amino acids for natural product synthesis. Molecules 2016, $21,951$. [CrossRef] [PubMed]

11. Kreis, L.M.; Carreira, E.M. Total synthesis of (-)-dendrobine. Angew. Chem. Int. Ed. 2012, 51, 3436-3439. [CrossRef] [PubMed]

12. Suzuki, H.; Keimatsu, I.; Ito, K. Über die alkaloide der chinesischen droge "Chin-Shih-Hu". (II. Mitteil.). Über dendrobin. (I). J. Pharm. Soc. Jpn. 1932, 52, 1049-3439. (In German) [CrossRef]

13. Suzuki, H.; Keimatsu, I.; Ito, K. Über die Alkaloide der chinesischen droge "Chin-Shin-Hu” (III. Mitteil.). Über das dendrobin. (II). J. Pharm. Soc. Jpn. 1934, 54, 801-819. (In German) [CrossRef]

14. Costa, J.S.; Dias, A.G.; Anholeto, A.L.; Monteiro, M.D.; Patrocinio, V.L.; Costa, P.R.R. Syn-selective Michael addition of nitromethane derivatives to enoates derived from $(R)-(+)$-glyceraldehyde acetonide. J. Org. Chem. 1997, 62, 4002-4006. [CrossRef]

15. Harada, S.; Sakai, T.; Takasu, K.; Yamada, K.; Yamamoto, Y.; Tomioka, K. Total synthesis of (-)-kopsinine by an asymmetric one-pot [N+2+3] cyclization. Chem. Asian J. 2012, 7, 2196-2198. [CrossRef] [PubMed]

16. Crow, W.D.; Michael, M. The alkaloids of Kopsia longflora Merrill I. isolation of the alkaloids. Aust. J. Chem. 1955, 8, 129-135. [CrossRef]

17. Crow, W.D.; Michael, M. Alkaloids of the Australian Apocynaceae: Kopsia longiflora Merr. III. preliminary Degradation of the Alkaloids. Aust. J. Chem. 1962, 15, 130-138. [CrossRef]

18. Ravindar, K.; Caron, P.-Y.; Deslongchamps, P. Total synthesis of (+)-cassaine utilizing an anionic polycyclization strategy. Org. Lett. 2013, 15, 6270-6273. [CrossRef] [PubMed]

19. Dalma, G. New alkaloids in Erythrophleum guineense. Ann. Chim. Appl. 1935, 25, 569-571.

20. Caron, P.-Y.; Deslongchamps, P. Versatile strategy to access tricycles related to quassinoids and triterpenes. Org. Lett. 2010, 12, 508-511. [CrossRef] [PubMed]

21. Lu, H.-H.; Martinez, M.D.; Shenvi, R.A. An eight-step gram-scale synthesis of (-)-jiadifenolide. Nat. Chem. 2015, 7, 604-607. [CrossRef] [PubMed]

22. Kubo, M.; Okada, C.; Huang, J.-M.; Harada, K.; Hioki, H.; Fukuyama, Y. Novel pentacyclic seco-prezizaane-type sesquiterpenoids with neurotrophic properties from Illicium jiadifengpi. Org. Lett. 2009, 11, 5190-5193. [CrossRef] [PubMed]

23. Hirasawa, Y.; Morita, H.; Shiro, M.; Kobayashi, J. Sieboldine A, a novel tetracyclic alkaloid from Lycopodium sieboldii, inhibiting acetylcholinesterase. Org. Lett. 2003, 5, 3991-3993. [CrossRef] [PubMed]

24. Canham, S.M.; France, D.J.; Overman, L.E. Total synthesis of (+)-sieboldine A. J. Am. Chem. Soc. 2010, 132, 7876-7877. [CrossRef] [PubMed] 
25. Canham, S.M.; France, D.J.; Overman, L.E. Total synthesis of (+)-sieboldine A: Evolution of a pinacol-terminated cyclization strategy. J. Org. Chem. 2013, 78, 9-34. [CrossRef] [PubMed]

26. Sennhenn, P.; Gabler, B.; Helmchen, G. Enantiomerically pure cycloalkenylacetic acid derivatives via Pd-catalyzed asymmetric allylic alkylation and subsequent enantiomeric enrichment via iodolactones. Tetrahedron Lett. 1994, 35, 8595-8598. [CrossRef]

27. Ernst, M.; Helmchen, G. A new synthesis route to enantiomerically pure jasmonoids. Angew. Chem. Int. Ed. 2002, 41, 4054-4056. [CrossRef]

28. Ghosh, A.K.; Cheng, X. Enantioselective total synthesis of (-)-zampanolide, a potent microtubule-stabilizing agent. Org. Lett. 2011, 13, 4108-4111. [CrossRef] [PubMed]

29. Ghosh, A.K.; Cheng, X.; Bai, R.; Hamel, E. Total synthesis of potent antitumor macrolide (-)-zampanolide: An oxidative intramolecular cyclization-based strategy. Eur. J. Org. Chem. 2012, 2012, 4130-4139. [CrossRef] [PubMed]

30. Tanaka, J.; Higa, T. Zampanolide, a new cytotoxic macrolide from a marine sponge. Tetrahedron Lett. 1996, 37, 5535-5538. [CrossRef]

31. Field, J.J.; Singh, A.J.; Kanakkanthara, A.; Halafihi, T.; Northcote, P.T.; Miller, J.H. Microtubule-stabilizing activity of zampanolide, a potent macrolide isolated from the Tongan marine sponge Cacospongia mycofijiensis. J. Med. Chem. 2009, 52, 7328-7332. [CrossRef] [PubMed]

32. Kitamura, M.; Ohkuma, T.; Inoue, S.; Sayo, N.; Kumobayashi, H.; Akutagawa, S.; Ohta, T.; Takaya, H.; Noyori, R. Homogeneous asymmetric hydrogenation of functionalized ketones. J. Am. Chem. Soc. 1988, 110, 629-631. [CrossRef]

33. McCandlish, L.E.; Hanson, J.C.; Stout, G.H. The structures of two derivatives of bicyclo[3,3,1]nonane2,4,9-trione. A natural product: Clusianone, $\mathrm{C}_{33} \mathrm{H}_{42} \mathrm{O}_{4}$, and trimethylated catechinic acid, $\mathrm{C}_{18} \mathrm{H}_{20} \mathrm{O}_{6}$. Acta Crystallogr. Sect. B 1976, 32, 1793-1801. [CrossRef]

34. Boyce, J.H.; Porco, J.A., Jr. Asymmetric, stereodivergent synthesis of (-)-clusianone utilizing a biomimetic cationic cyclization. Angew. Chem. Int. Ed. 2014, 53, 7832-7837. [CrossRef] [PubMed]

35. Azuma, M.; Yoshikawa, T.; Kogure, N.; Kitajima, M.; Takayama, H. Biogenetically inspired total syntheses of Lycopodium alkaloids, (+)-flabellidine and (-)-lycodine. J. Am. Chem. Soc. 2014, 136, 11618-11621. [CrossRef] [PubMed]

36. Manske, R.H.F.; Marion, L. The alkaloids of Lycopodium species: I. Lycopodium complanatum L. Can. J. Res. 1942, 20b, 87-92. [CrossRef]

37. Anet, F.A.L.; Eves, C.R. Lycodine, a new alkaloid of Lycopodium annotinum. Can. J. Chem. 1958, 36, $902-909$. [CrossRef]

38. Nakayama, A.; Kogure, N.; Kitajima, M.; Takayama, H. First asymmetric total syntheses of fawcettimine-type Lycopodium alkaloids, lycoposerramine-C and phlegmariurine-A. Org. Lett. 2009, 11, 5554-5557. [CrossRef] [PubMed]

39. Bödeker, K. Lycopodin, das erste alkaloïd der Gefässkryptogamen. Liebigs Ann. Chem. 1881, 208, 363-367. [CrossRef]

40. Ma, D.; Zhong, Z.; Liu, Z.; Zhang, M.; Xu, S.; Xu, D.; Song, D.; Xie, X.; She, X. Protecting-group-free total synthesis of (-)-lycopodine via phosphoric acid promoted alkyne aza-Prins cyclization. Org. Lett. 2016, 18, 4328-4331. [CrossRef] [PubMed]

41. Kozak, J.A.; Dake, G.R. Total synthesis of (+)-fawcettidine. Angew. Chem. Int. Ed. 2008, 47, 4221-4223. [CrossRef] [PubMed]

42. Inuki, S.; Iwata, A.; Oishi, S.; Fujii, N.; Ohno, H. Enantioselective total synthesis of (+)-lysergic acid, (+)-lysergol, and (+)-isolysergol by palladium-catalyzed domino cyclization of allenes bearing amino and bromoindolyl groups. J. Org. Chem. 2011, 76, 2072-2083. [CrossRef] [PubMed]

43. Agurell, S. Isolysergol from saprophytic cultures of ergot. Acta Pharm. Suec. 1966, 3, 7-10. [PubMed]

44. Mizuno, T.; Oonishi, Y.; Takimoto, M.; Sato, Y. Total synthesis of (-)-corynantheidine by nickel-catalyzed carboxylative cyclization of enynes. Eur. J. Org. Chem. 2011, 2011, 2606-2609. [CrossRef]

45. Janot, M.-M.; Goutarel, R. La corynanthéidine, nouvel alcaloide cristallisé isolé des écorces de Pseudocinchona africana. Aug. Chev. C. R. Acad. Sci. 1944, 218, 852-854. (In French)

46. Bailey, P.D.; Hollinshead, S.P.; McLay, N.R. Exceptional stereochemical control in the Pictet-Spengler reaction. Tetrahedron Lett. 1987, 28, 5177-5180. [CrossRef] 
47. Seo, H.; Yun, H.; Lee, S.; Jang, J.; Han, Y.T.; Kim, D.-D.; Lee, J.; Suh, Y.G. Stereoselective synthesis of 7-epi-incarvilline. Org. Lett. 2013, 15, 531-533. [CrossRef] [PubMed]

48. Chi, Y.-M.; Yan, W.-M.; Li, J.-S. An alkaloid from Incarvillea sinensis. Phytochemistry 1990, 29, $2376-2378$. [CrossRef]

49. Chi, Y.-M.; Yan, W.-M.; Chen, D.-C.; Hiroshi, N.; Yoichi, I.; Ushio, S. A monoterpene alkaloid from Incarvillea sinensis. Phytochemistry 1992, 31, 2930-2932. [CrossRef]

50. Chi, Y.-M.; Hashimoto, F.; Yan, W.-M.; Nohara, T. Two alkaloids from Incarvillea sinensis. Phytochemistry 1995, 39, 1485-1487. [CrossRef]

51. Lee, S.; Paek, S.-M.; Yun, H.; Kim, N.-J.; Suh, Y.-G. Enantioselective total synthesis of a natural iridoid. Org. Lett. 2011, 13, 3344-3347. [CrossRef] [PubMed]

52. Acebey, L.; Sauvain, M.; Beck, S.; Moulis, C.; Gimenez, A.; Jullian, V. Bolivianine, a new sesterpene with an unusual skeleton from Hedyosmum angustifolium, and its isomer, isobolivianine. Org. Lett. 2007, 9, 4693-4696. [CrossRef] [PubMed]

53. Yuan, C.; Du, B.; Yang, L.; Liu, B. Bioinspired total synthesis of bolivianine: A Diels-Alder/intramolecular hetero-Diels-Alder cascade approach. J. Am. Chem. Soc. 2013, 135, 9291-9294. [CrossRef] [PubMed]

54. Du, B.; Yuan, C.; Yu, T.; Yang, L.; Yang, Y.; Liu, B.; Qin, S. Asymmetric total synthesis of onoseriolide, bolivianine, and isobolivianine. Chem. Eur. J. 2014, 20, 2613-2622. [CrossRef] [PubMed]

55. Naruse, N.; Tenmyo, O.; Kawano, K.; Tomita, K.; Ohgusa, N.; Miyaki, T.; Konishi, M.; Oki, T. Fluvirucins $A_{1}$, $\mathrm{A}_{2}, \mathrm{~B}_{1}, \mathrm{~B}_{2}, \mathrm{~B}_{3}, \mathrm{~B}_{4}$ and $\mathrm{B}_{5}$, new antibiotics active against influenza A virus I. Production, isolation, chemical properties and biological activities. J. Antibiot. 1991, 44, 733-740. [CrossRef] [PubMed]

56. Naruse, N.; Tsuno, T.; Sawada, Y.; Konishi, M.; Oki, T. Fluvirucins $A_{1}, A_{2}, B_{1}, B_{2}, B_{3}, B_{4}$ and $B_{5}$, new antibiotics active against influenza A virus II. Structural determination. J. Antibiot. 1991, 44, 741-755. [CrossRef] [PubMed]

57. Naruse, N.; Konishi, M.; Oki, $T$. Fluvirucins $A_{1}, A_{2}, B_{1}, B_{2}, B_{3}, B_{4}$ and $B_{5}$, new antibiotics active against influenza A virus III. The stereochemistry and absolute configuration of fluvirucin $\mathrm{A}_{1}$. J. Antibiot. 1991, 44, 756-761. [CrossRef] [PubMed]

58. Tomita, K.; Oda, N.; Hoshino, Y.; Ohkusa, N.; Chikazawa, H. Fluvirucins $A_{1}, A_{2}, B_{1}, B_{2}, B_{3}, B_{4}$ and $B_{5}$, new antibiotics active against influenza A virus IV. Taxonomy on the producing organisms. J. Antibiot. 1991, 44, 940-948. [CrossRef] [PubMed]

59. Hegde, V.R.; Patel, M.G.; Gullo, V.P.; Ganguly, A.K.; Sarre, O.; Puar, M.S. Macrolactams: A new class of antifungal agents. J. Am. Chem. Soc. 1990, 112, 6403-6405. [CrossRef]

60. Hegde, V.; Patel, M.; Horan, A.; Gullo, V.; Marquez, J.; Gunnarsson, I.; Gentile, F.; Loebenberg, D.; King, A. Macrolactams: A novel class of antifungal antibiotics produced by Actinomadura spp. SCC 1776 and SCC 1777. J. Antibiot. 1992, 45, 624-632. [CrossRef] [PubMed]

61. Suh, Y.-G.; Lee, Y.-S.; Kim, S.-H.; Jung, J.-K.; Yun, H.; Jang, J.; Kim, N.-J.; Jung, J.-W. A stereo-controlled access to functionalized macrolactams via an aza-Claisen rearrangement. Org. Biomol. Chem. 2012, 10, 561-568. [CrossRef] [PubMed]

62. Lee, Y.S.; Jung, J.W.; Kim, S.H.; Jung, J.K.; Paek, S.M.; Kim, N.J.; Chang, D.J.; Lee, J.; Suh, Y.G. First total synthesis and structural confirmation of fluvirucinine $\mathrm{A}_{2}$ via an iterative ring expansion strategy. Org. Lett. 2010, 12, 2040-2043. [CrossRef] [PubMed]

63. Yan, Y.M.; Ai, J.; Zhou, L.L.; Chung, A.C.K.; Li, R.; Nie, J.; Fang, P.; Wang, X.L.; Luo, J.; Hu, Q.; et al. Lingzhiols, Unprecedented Rotary Door-Shaped Meroterpenoids as Potent and Selective Inhibitors of p-Smad3 from Ganoderma lucidum. Org. Lett. 2013, 15, 5488-5491. [CrossRef] [PubMed]

64. Long, R.; Huang, J.; Shao, W.; Liu, S.; Lan, Y.; Gong, J.; Yang, Z. Asymmetric total synthesis of (-)-lingzhiol via a Rh-catalysed [3 + 2] cycloaddition. Nat. Commun. 2014, 5, 5707-5716. [CrossRef] [PubMed]

65. Justik, M.W.; Koser, G.F. Oxidative rearrangements of arylalkenes with [hydroxy(tosyloxy)iodo]benzene in 95\% methanol: A general, regiospecific synthesis of $\alpha$-aryl ketones. Tetrahedron Lett. 2004, 45, 6159-6163. [CrossRef]

66. González, D.F.; Brand, J.P.; Waser, J. Ethynyl-1,2-benziodoxol-3(1H)-one (EBX): An exceptional reagent for the ethynylation of keto, cyano, and nitro esters. Chem. Eur. J. 2010, 16, 9457-9461. [CrossRef] [PubMed]

67. Hong, A.Y.; Vanderwal, C.D. A synthesis of alsmaphorazine B demonstrates the chemical feasibility of a new biogenetic hypothesis. J. Am. Chem. Soc. 2015, 137, 7306-7309. [CrossRef] [PubMed] 
68. Koyama, K.; Hirasawa, Y.; Nugroho, A.E.; Hosoya, T.; Hoe, T.C.; Chan, K.L.; Morita, H. Alsmaphorazines A and B, novel indole alkaloids from Alstonia pneumatophore. Org. Lett. 2010, 12, 4188-4191. [CrossRef] [PubMed]

69. Hyeon, S.-B.; Ozaki, A.; Suzuki, A.; Tamura, S. Isolation of $\alpha \beta$-dehydrocurvularin and $\beta$-hydroxycurvularin from Alternaria tomato as sporulation-suppressing factors. Agric. Biol. Chem. 1976, 40, 1663-1664.

70. Choe, H.; Pham, T.T.; Lee, J.Y.; Latif, M.; Park, H.; Kang, Y.K.; Lee, J. Remote stereoinductive intramolecular nitrile oxide cycloaddition: Asymmetric total synthesis and structure revision of $(-)$-11 $\beta$-hydroxycurvularin. J. Org. Chem. 2016, 81, 2612-2617. [CrossRef] [PubMed]

71. Shing, T.K.M.; Zhong, Y.-L. Synthesis of medium-sized cyclic ethers from carbohydrates via an intramolecular nitrile oxide-alkene cycloaddtion strategy. Synlett 2006, 1205-1208. [CrossRef]

72. Kou, K.G.M.; Li, B.X.; Lee, J.C.; Gallego, G.M.; Lebold, T.P.; DiPasquale, A.G.; Sarpong, R. Syntheses of denudatine diterpenoid alkaloids: Cochlearenine, $N$-ethyl-1 $\alpha$-hydroxy-17-veratroyldictyzine, and paniculamine. J. Am. Chem. Soc. 2016, 138, 10830-10833. [CrossRef] [PubMed]

73. Kolak, U.; Öztürk, M.; Özgökçe, F.; Ulubelen, A. Norditerpene alkaloids from Delphinium linearilobum and antioxidant activity. Phytochemistry 2006, 67, 2170-2175. [CrossRef] [PubMed]

74. Wada, K.; Kawahara, N. Diterpenoid and norditerpenoid alkaloids from the roots of Aconitum yesoense var. macroyesoense. Helv. Chim. Acta 2009, 92, 629-637. [CrossRef]

75. Marth, C.J.; Gallego, G.M.; Lee, J.C.; Lebold, T.P.; Kulyk, S.; Kou, K.G.M.; Qin, J.; Lilien, R.; Sarpong, R. Network-analysis-guided synthesis of weisaconitine D and liljestrandinine. Nature 2015, 528, 493-498. [CrossRef] [PubMed]

76. Smith, M.W.; Snyder, S.A. A concise total synthesis of (+)-scholarisine A empowered by a unique C-H arylation. J. Am. Chem. Soc. 2013, 135, 12964-12967. [CrossRef] [PubMed]

77. Cai, X.H.; Tan, Q.G.; Liu, Y.P.; Feng, T.; Du, Z.Z.; Li, W.Q.; Luo, X.D. A cage-monoterpene indole alkaloid from Alstonia scholaris. Org. Lett. 2008, 10, 577-580. [CrossRef] [PubMed]

78. Ageno, G.; Banfi, L.; Cascio, G.; Guanti, G.; Manghisi, E.; Riva, R.; Rocca, V. Enantiospecific and diastereoselective synthesis of 4,4-disubstituted-3-amino-2-azetidinones, starting from D-serine. Tetrahedron 1995, 51, 8121-8134. [CrossRef]

79. Reddy, L.R.; Fournier, J.-F.; Reddy, B.V.S.; Corey, E.J. An efficient, stereocontrolled synthesis of a potent omuralide-salinosporin hybrid for selective proteasome inhibition. J. Am. Chem. Soc. 2005, 127, 8974-8976. [CrossRef] [PubMed]

80. Lu, P.; Gu, Z.; Zakarian, A. Total synthesis of maoecrystal V: Early-stage C-H functionalization and lactone assembly by radical cyclization. J. Am. Chem. Soc. 2013, 135, 14552-14555. [CrossRef] [PubMed]

81. Li, S.-H.; Wang, J.; Niu, X.-M.; Shen, Y.-H.; Zhang, H.-J.; Sun, H.-D.; Li, M.-L.; Tian, Q.-E.; Lu, Y.; Cao, P.; et al. Maoecrystal $\mathrm{V}$, cytotoxic diterpenoid with a novel $\mathrm{C}_{19}$ skeleton from Isodon eriocalyx (Dunn.) Hara. Org. Lett. 2004, 6, 4327-4330. [CrossRef] [PubMed]

82. Guo, S.; Liu, J.; Ma, D. Total synthesis of leucosceptroids A and B. Angew. Chem. Int. Ed. 2015, 54, $1298-1301$. [CrossRef] [PubMed]

83. Luo, S.-H.; Luo, Q.; Niu, X.-M.; Xie, M.-J.; Zhao, X.; Schneider, B.; Gershenzon, J.; Li, S.-H. Glandular trichomes of Leucosceptrum canum harbor defensive sesterterpenoids. Angew. Chem. Int. Ed. 2010, 49, 4471-4475. [CrossRef] [PubMed]

84. Kawamata, T.; Nagatomo, M.; Inoue, M. Total synthesis of zaragozic acid C: Implementation of photochemical C $\left(\mathrm{sp}^{3}\right)-\mathrm{H}$ acylation. J. Am. Chem. Soc. 2017, 139, 1814-1817. [CrossRef] [PubMed]

85. Dufresne, C.; Wilson, K.E.; Zink, D.; Smith, J.; Bergstrom, J.D.; Kurtz, M.; Rew, D.; Nallin, M.; Jenkins, R.; Bartizal, K.; et al. The isolation and structure elucidation of zaragozic acid $C$, a novel potent squalene synthase inhibitor. Tetrahedron 1992, 48, 10221-10226. [CrossRef]

(C) 2017 by the authors. Licensee MDPI, Basel, Switzerland. This article is an open access article distributed under the terms and conditions of the Creative Commons Attribution (CC BY) license (http://creativecommons.org/licenses/by/4.0/). 